\title{
LATIN AMERICAN POPULAR ART IN A MUSEUM: HOW THINGS BECOME ART
}

\section{INTRODUCTION}

When the Universidad de Chile celebrated its centennial in 1943, all of the Latin American countries were invited to participate in its commemorative events. ${ }^{1}$ One of them was the Exhibition of American ${ }^{2}$ Popular Art at the Museo Nacional de Bellas Artes (National Museum of Fine Arts), which brought together objects from participating countries. ${ }^{3}$ The Universidad de Chile's invitation asked countries to send functional objects that were part of their people's daily lives. The exhibition was very successful, critically acclaimed, and very well attended. ${ }^{4}$ But above all, it planted the seed for what was to become the Museo de Arte Popular Americano MAPA (Museum of American Popular Art), functioning to this day.

In this essay, I intend to show the objects chosen by Latin American countries to be a part of the exhibition and the related discussions that appeared in the exhibition catalogue. When their function and physical context changed, so did their value: they became museum objects. This process is ex-

${ }^{1}$ A Spanish version of this article - in that case focusing on the circulation of objects in Latin America - will appear as a chapter in the book to be published by Chile's Pontificia Universidad Católica and Colombia's Universidad de los Andes.

I would like to thank my assistants Francisca Valenzuela and José Araneda for all their helpful ideas and readings of this article.

${ }^{2}$ In this article, reference is made to "American" popular arts in a temporary exhibition and a permanent museum. "American" in this context refers to the countries of North America and South American (with the exception of Canada and the United States in the case of this study). In Spanish, "lo americano" refers to the continents in their entirety, while in English it can be confused with the name for citizens of the United States.

${ }^{3}$ Both the National Museum of Fine Arts and the MAPA are located in Santiago de Chile.

${ }_{4}$ This issue will be developed later on in this article. 
plained by a series of contexts, actors and institutions: the new value ascribed to Latin American arts since the twentieth century; specific incarnations of Americanism during the Second World War; the Latin American perspective, in general, and the Chilean perspective of the university's role in society, in particular. I propose that these objects had three stages in their social lives: they were first objects used in peoples' daily lives; they were then considered objects which deserved to be exhibited in the National Museum of Fine Arts; and finally, they remained as part of the permanent collection of the Museum of American Popular Art.

This article reveals the way that an object's value might evolve. To some people Latin American Popular Art objects represented peace amidst the destruction of World War II. The objects on display were perceived as incarnations of Latin American cultural identity and historiography subsequently assigned Latin American culture with the role of contributor to peace efforts. Moreover, the article addresses a collection that has been given little consideration by art historiography. An important exception is the article by Constanza Acuna, which reviews the history of the museum to date. While that article is for a mass audience, it does establish the main issues associated with the creation and history of the museum. ${ }^{5}$ Motivated by the lack of academic work about the museum and inspired by the historical data available, I propose a new reading of the phenomenon. The historical data I use are the photographs of the exhibition pieces, as well as the exhibition catalogue. For the historical context, I use documents written by those involved, official diplomatic documents and publications from the press of the time.

\section{THE OBJECTS AND THEIR ASSOCIATED DISCOURSE}

The countries invited sent a significant number of popular art objects to the exhibition. ${ }^{6}$ In the catalogue of the event, each country sent a list enumerating the objects and offering basic information about their material, colour, function and sometimes a description of their morphological form, place of origin and dimensions. The objects from countries that did

${ }^{5}$ C. Acuńa, Origen y devenir del Museo de Arte Popular Tomás Lago; pdf available online: <http://www.mapa.uchile.cl/proyectos/index.php> [accessed: May 16, 2018].

${ }^{6}$ Because the exhibition contained more than 2500 objects, it is not possible to provide a complete list. For this reason, I include a list of the categories of objects chosen by each country. 
not appear in the catalogue (Guatemala and Paraguay) were not registered due to delays in their shipment. There is no precise number available for the objects from Chile, because the catalogue presents them by category, not individually. Qualitatively, the Chilean objects were very diverse. An appendix reveals that there were also many collections from the Mapuche people, ${ }^{7}$ including silver objects, wooden objects, boleadoras (a hunting tool), rocks, hoes and axes. There were also almost 80 objects from the Clarisses Nuns' private ceramics collection; objects from Easter Island; and huaso ${ }^{8}$ saddlery and implements. A group of Quincahamalí ${ }^{9}$ ceramics was also included (Fig. 1).

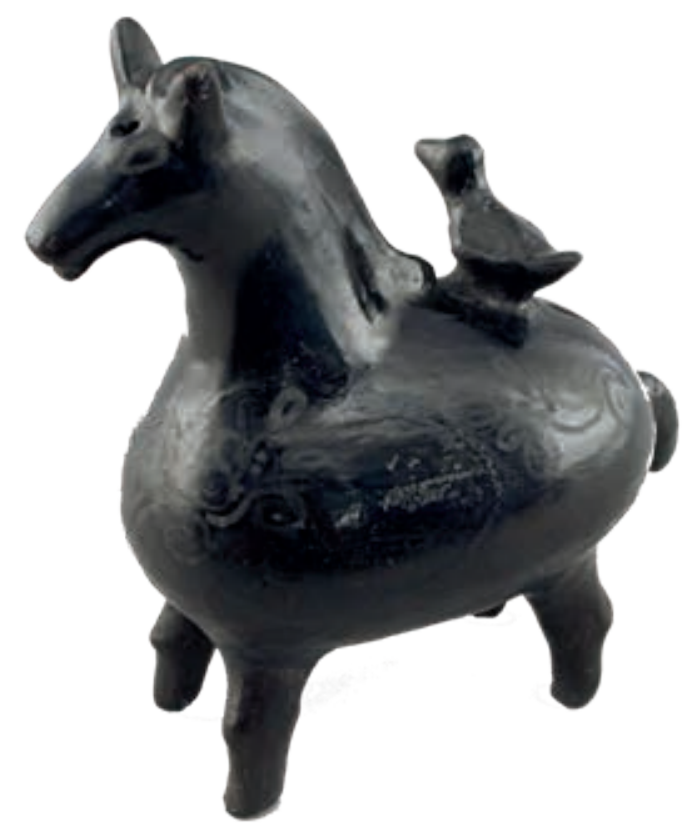

1.Moneybox, horsewithbird, unknownauthor, ca 1940, Quinchamalí. Chile, clay, $16,5 \mathrm{~cm} \times 21 \mathrm{~cm}, \mathrm{MAPA}$ Collection, Universidad de Chile

7 Mapuche or "man of the earth" is the name of one of southern Chile's and Argentina's indigenous peoples.

8 The huaso is a popular Chilean male figure: a man of the countryside.

9 Quinchamalí is a little town 400 kilometers south of Santiago de Chile. 
Among the objects from Argentina, only textiles were chosen (ponchos, chuspas, ${ }^{10}$ belts and rugs). Bolivia sent many specimens (around 850), which revealed a diversity of materials and uses: many ceramic pieces and wooden objects, as well as textiles, and gold and metal work. Furthermore, they participated in terms of music and dance objects, and with another category they themselves defined as "other expressions of popular art", which included ekekos (god of abundance figures), toys and miniatures.

Colombia sent several ceramic objects, many tagua-wood miniatures, and wooden and leather objects, as well as straw hats (Fig. 2). Mexico, for its part, sent objects according to their region of origin (Fig. 3 and Fig. 4). Peru offered textiles and explicitly pointed out that they were made from alpaca and sheep wool. There were also "cloth" textiles, baskets and other straw objects; wooden miniatures representing popular figures; painted plaster figures, among them a nativity scene; and clay figures. We include here a picture of the typical "mate" (receptacle for drinking tea) (Fig. 5). Venezuela sent objects from a private collection consisting of hammocks and other objects made from cocuiza wood, several straw objects and others made with coconut. Jewellery made with "Chocano" gold is also mentioned.

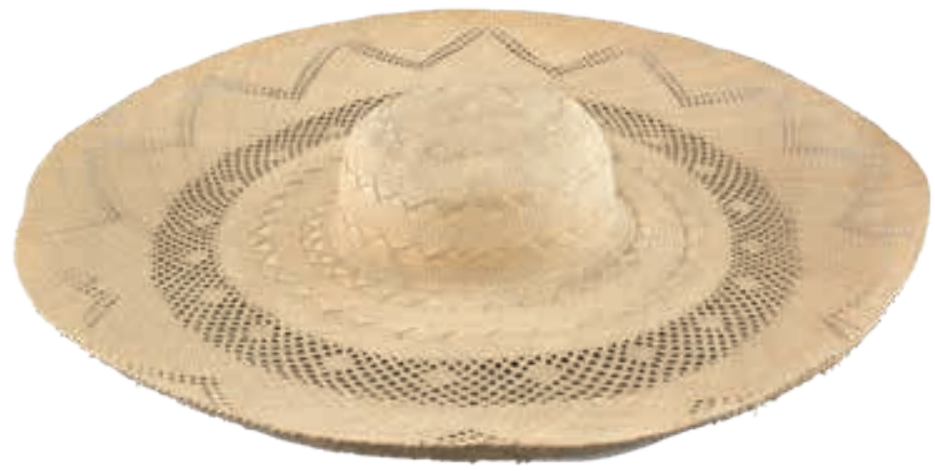

2. Hat, Unknown author, ca 1943, Colombia, straw, $46 \mathrm{~cm}$ diameter, MAPA Collection, Universidad de Chile

${ }^{10}$ Chuspas are bags used to carry coca leaves in the Andean region. 
3. Exvoto, Unknown author, ca 1932, Morelia, Michoacán, México, oil on brass, $24,7 \times 17,9 \times 0.6 \mathrm{~cm}, \mathrm{MAPA}$ Collection, Universidad de Chile
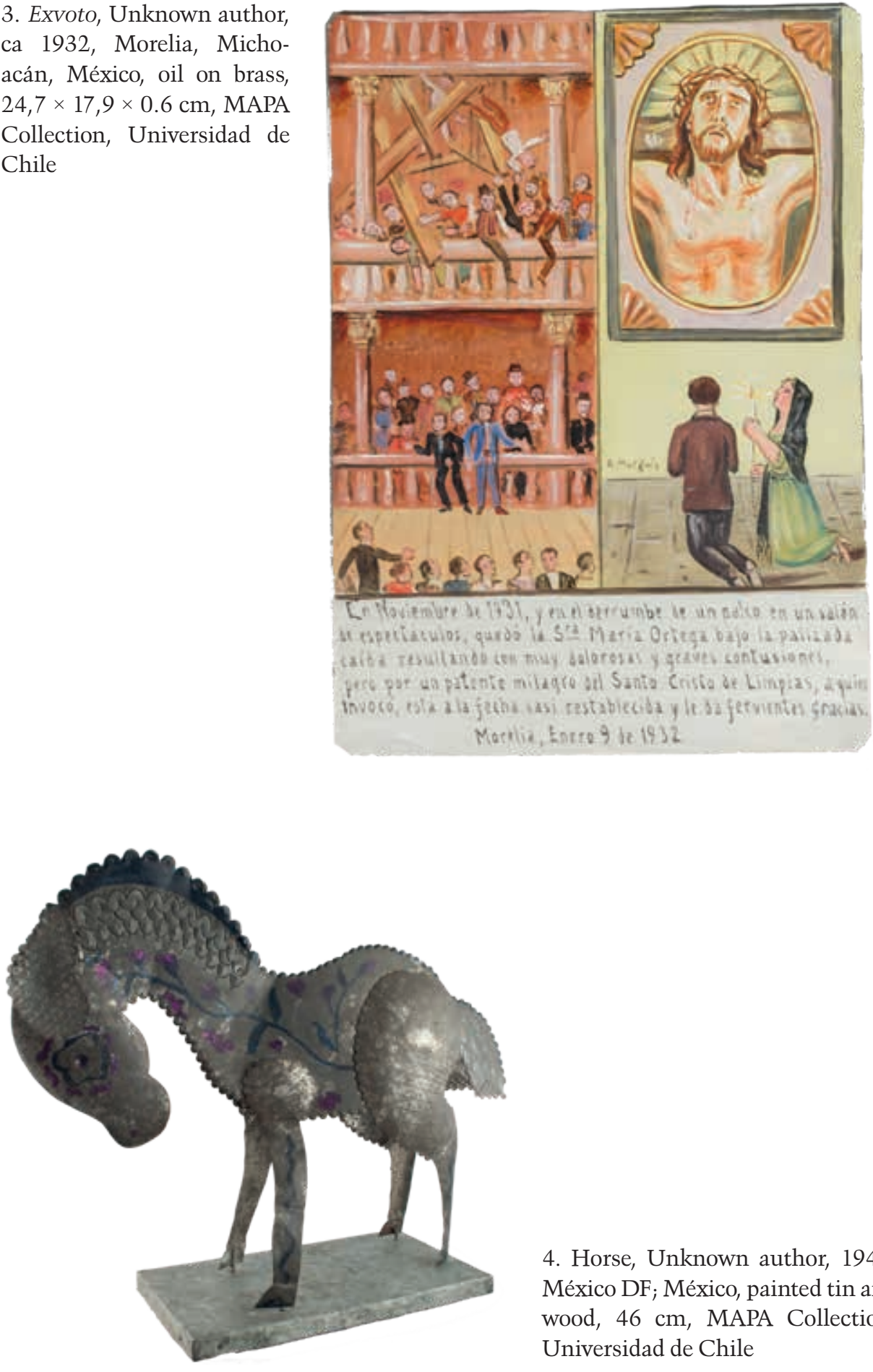

4. Horse, Unknown author, 1940, México DF; México, painted tin and wood, $46 \mathrm{~cm}$, MAPA Collection, Universidad de Chile 


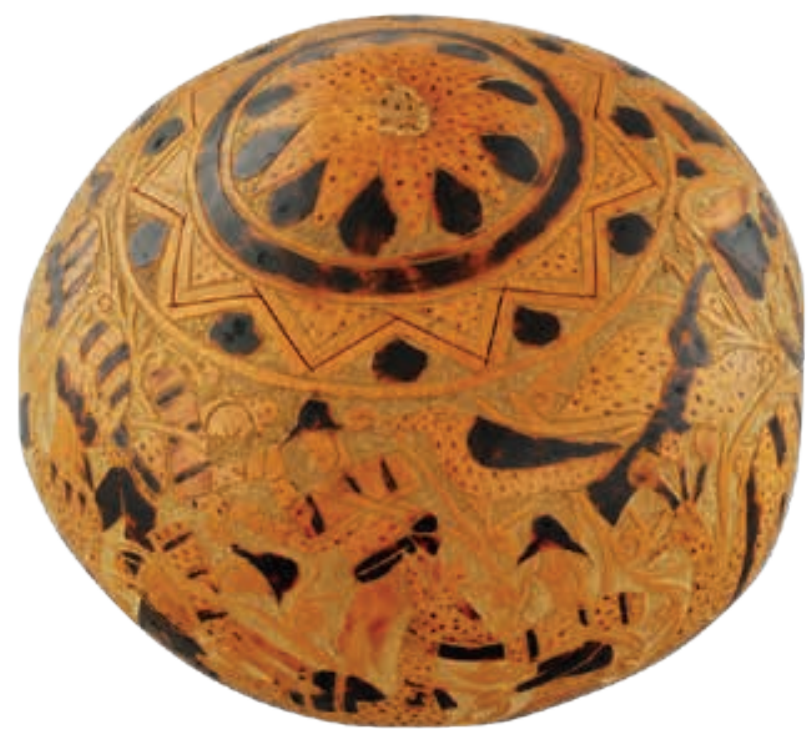

5. Mate (recipient to drink a type of tea), unknown author, ca 1943, Cochas, Junín, Perú, pumpkin, 14 cm, diameter $17 \mathrm{~cm}$, MAPA Collection, Universidad de Chile

Values represented by these objects

The objects were chosen to celebrate the anniversary of the Universidad de Chile and in consideration of a permanent museum. What was the idea behind this? The objects that were chosen for the collection (first a temporary exhibition, which then led to the first permanent exhibition during the subsequent stage) were representative of ideas and identities, but also revealed the agendas, processes and relationships of the people who chose, classified, observed, decoded and valued them. The objects in each country's respective collection were signs and indicators of specific collective ways of understanding reality. ${ }^{11}$ They were artefacts that not only expressed technological solutions to specific needs, but also expressed cultural forms of reflecting values. Exhibiting these objects, they were betting on the objects' ability to exemplify and demonstrate, through their presence alone, a series of histories and values that were most likely better communicated in this way than through words.

${ }^{11}$ M. González de Oleaga, E. Bohoslavsky, M. di Liscia, "Entre el desafío y el signo. Identidad y diferencia en el Museo de América de Madrid", Alteridades 2011, 21(41), p. 1. 
Words categorize things; objects, on the other hand, by their very presence, show a concrete specimen.

Museums are not only spaces for displaying object or exhibits; in fact, they articulate and transmit ideas to the rest of society. In this sense, they are always political entities. When popular arts objects were chosen to commemorate something as important to Chile as the centennial of its first public university, they grew in meaning and value in terms of national identity and a shared Latin American identity that society longed for.

The collections that people and institutions organize over a certain period of time provide a way of representing and visualizing reality. As the museum was considered a way to exhibit objects with inherent identities and messages, it participated in the Western, post-French Revolution tradition of conserving and exhibiting the people's common cultural heritage. ${ }^{12}$ In this case, it did so for a group of nations who shared a common identity. However, the museum was also capable of developing the educational and political work of bringing works of art closer to the general public and of fostering adhesion to a collective truth and to certain truths over others. ${ }^{13}$

Tomás Lago, the exhibition curator, considered the participating objects to be "live objects", because they were serving as ambassadors for their countries and because they were not out-of-use artefacts (in fact, he called them functional objects ${ }^{14}$ ), but rather had relevance at the time, completing the functions of daily life. Furthermore, they were considered to be genuinely Latin American and reflective of the historical-cultural processes in Latin American countries. ${ }^{15}$ They were, therefore, highly valuable objects to the participating actors and institutions and once in the exhibition they became visually interesting objects, subject to appreciation. ${ }^{16}$

Analysing the written information in the catalogue, we can say that the objects involved in the show represented an interpretation of Latin American history. The authors shed light on the fact that artists used raw materials from their surroundings to create unique objects. Despite the diversity of

12 E. Rinesi, "El museo como ideología y como posibilidad", in: Museos. Arte e Identidad. Artesanías en la idea de nación, compiled by E. Rinesi, Buenos Aires 2011, p. 11.

${ }^{13}$ I. Karp, S.D. Lavine, "Introduction: Museums and Multiculturalism", in: The Poetics and Politics of Museum Displays, eds. I. Karp and S.D. Lavine, Washington-London, 1991, p. 1.

14 T. Lago, "Las Artes Populares en Chile", in: Catálogo Exposición Artes Americanas. Realizada con motivo del Primer Centenario de la Universidad de Chile, Santiago de Chile 1943, p. 73.

15 A. Labarca, "Prefacio", ibidem, p. 10.

16 S. Alpers, "The Museum as a Way of Seeing", in: The Poetics and Politics of Museum Displays, p. 25 and 29. 
the exhibited Latin American popular art objects, the influence of both the European and Latin American civilizations, considered not only different but opposite in nature, was apparent.

The objects were considered part of a heritage that remembered that the old world political upheaval had to be overcome so that the Latin American way of life could blossom and shoulder its historic responsibility. The objects demonstrated Latin American efforts to break with a colonial past tied to Europe and instead to recognize the elements common to the entire continent. At the same time, they made it possible to realize that the historical reality of each Latin American country was similar to the others. ${ }^{17}$ In the same way, the objects selected to be put on display represented the present, since they were supposed to be in use. Finally, the interpretation meant for these objects was that of hope for a future in which Latin America had something to say. In fact, Alfredo Aliaga, a critic who attended the exhibition praised the Universidad de Chile for having placed value on those objects that could serve as a basis for future study: "it seems that forthcoming eras will bring a new world order in terms of studies, at least as far as their breadth and ways of approaching aspects only partially considered until this point in history".$^{18}$

Each country participating in the exhibition wrote a text to present its collection. Bernardo Canal Feijoo, the Argentine who wrote about Argentinian objects at the exhibition, stated it was important to redefine what Latin American art was through these objects. ${ }^{19}$ He pointed out which elements were Spanish and which were indigenous. He argued that the indigenous influence was more evident in textiles, pottery and ceramics. The Bolivian curator, Enrique Sánchez Narváez, had similar ideas, claiming that Bolivian popular art had nothing to do with Tiwanaku ${ }^{20}$ or Tawantinsuyu, ${ }^{21}$ but rather was new and different. He later mentioned the destructive effect the Spanish had on the local cultures, whose artistic spirit was stronger than that of the colonizer. ${ }^{22}$

To describe Chilean popular arts, Tomás Lago also used objects to offer a historic interpretation: the objects demonstrate, through their style, that

17 Ibidem, p. 7.

18 A. Aliaga, "Exposición de Arte Popular Americano", En Viaje June 1943, pp. 52-53. Throughout this text all translations from Spanish were made by Suzanne Roberts, unless indicated otherwise.

19 B. Canal Feijoo, "Argentina" in: Catálogo Exposición Artes Americanas, pp. 15-16.

20 The name of an Andean culture and its main city. It existed from 1500 BCE to 1000 $\mathrm{AD}$. The ruins of the city are located in the vicinity of La Paz, Bolivia.

21 The name given to the Inca Empire in the Andean world. It existed from 1439 to 1533, when it was conquered by the Spanish.

22 E. Sánchez Narváez, "Bolivia", in: Catálogo Exposición Artes Americanas, p. 22. 
the indigenous people were exterminated and absorbed and that, "as a result, in comparison with other Latin American countries, Chile's popular art is primitive, entirely creole, very personal in some of the traditional industries (pottery, saddlery), naïve, emotional and balanced". ${ }^{23}$

The Colombian curator, whose name does not appear in the catalogue, also lent a sense of history to his objects by speaking of the pre-Columbian origins of many aspects of his country. Mompós ceramics and tagua-wood crafts are said to have existed long before the arrival of the Spanish conquistadors. ${ }^{24}$ Venezuela and Peru (through the texts of Armando Lira and Luis E Valcárcel respectively) also held to this claim about indigenous origins and subsequent Spanish influence. ${ }^{25}$

The prioritization of the exhibition and its catalogue, permanent documentation of what needed to be said about Latin American arts at the time, demonstrate the willingness of each country to define its own concepts, insert its own paradigms and choose its own objects to remain at the museum. Each curator defined both that which was unique to their country and what was shared by the entire continent, while establishing keys to decoding their popular art. Points of comparison included: indigenous and Spanish influences; the influence of Asian products that had arrived in Latin America during colonial times; trend timelines; details of iconography and technique; and the indigenous appropriation of Spanish tools.

\section{THE HISTORICAL CONTEXT: IDEAS}

\section{How "Popular Art" was understood}

The objects selected, which served as mediators, agents, creators of frameworks within which social relationships were developed, ${ }^{26}$ represented the popular arts ${ }^{27}$ of the countries that participated in the Universidad de Chile's

${ }^{23}$ Lago, "Las Artes Populares en Chile", p. 74.

24 Catálogo Exposición Artes Americanas, p. 26.

25 Ibidem, p. 199.

26 T. Dant, Material culture in the social world: values, activities, lifestyles, Buckingham 1999, p. 1.

${ }^{27}$ I am not using "popular arts" according to its current definition. The term is instead used as it was during the time period of interest to us. However, I will include popular art in the general sphere of art, a valuation of the aesthetic nature of an object intentionally brought into existence by an artist. Popular art is art based upon the theory that considers art anything aesthetically beautiful or attractive. There is a second theory that considers art to be anything that falls into the category, because it lies within a certain system of 
Exposición de Artes Populares Americanas (Exhibition of Popular American Art) in 1943.

In the 1940s, Latin America understood popular art to be those objects that embodied perennial traditions, an immediate expression of life's necessities. They were, therefore, arts that related the creators with their immediate surroundings and local materials. Techniques and aesthetics were applied to the materials in order that they would become useful to daily life. Popular art objects embodied the popular culture paradigm, in contrast to that of high culture. Each of these two components, usually in a kind of tension with one another, had their own objects, actors, theories and stages. However, at the beginning of the 1930s it was possible for both paradigms to function simultaneously. ${ }^{28}$ Tomás Lago (1903-1975), one of the protagonists of Chilean history, was a man who moved in many different circles, conducting research and publishing on both paradigms. He was born in Chillán, south of Chile's capital, Santiago, and dedicated much of his life to the vindication of traditional culture and the popular arts. His contributions also include the study of the "fine arts," largely referring to painting, and his writings suggest an extensive conceptual background. ${ }^{29}$ In his book Arte Popular Chileno (Chilean Popular Art), Lago devotes much more attention to a diagnostic of the state of Chilean popular arts than he does to defining what this concept encompasses, as if it were for him an idea that requires little further explanation than to say it is a part of folklore. ${ }^{30}$ In his writing, he warns against the threat posed to popular arts by the excess of industrialization and widespread communications. For him, these processes implied the loss of tradition (Fig. 6). ${ }^{31}$

ideas. In this case, I think that Latin American popular art could be considered art during the time period of interest to us, because the system of ideas surrounding it was subject to a process of redefinition. Finally, there is the institutional theory, which claims that as long as an institutional system holds up an object as art, it is art. Latin American popular art's entrance into museums supports the idea that the popular arts were considered art during the time period of interest to us. These three theories are detailed in Alfred Gell's article, "Vogel's Net: Traps as Artworks and Artworks as art", Journal of Material Culture 1996, $1(15)$, pp. 15-16.

${ }_{28}$ B. Subercaseaux, Historia de las Ideas y de la Cultura en Chile. Volumen III, Santiago 2011, p. 100.

29 A. Ferrer Orts, A. Madrid Letelier, "Las grandes líneas maestras de la historiografía artística chilena (1928-1965)", Saitabi. Revista de la Facultat de Geografía i Historia, 2016, 66, p. 261.

30 Tomás Lago defines folklore as what people know and what is known about them.

T. Lago, Arte Popular Chileno, Santiago 1971, p. 13.

31 Ibidem, p. 10. 


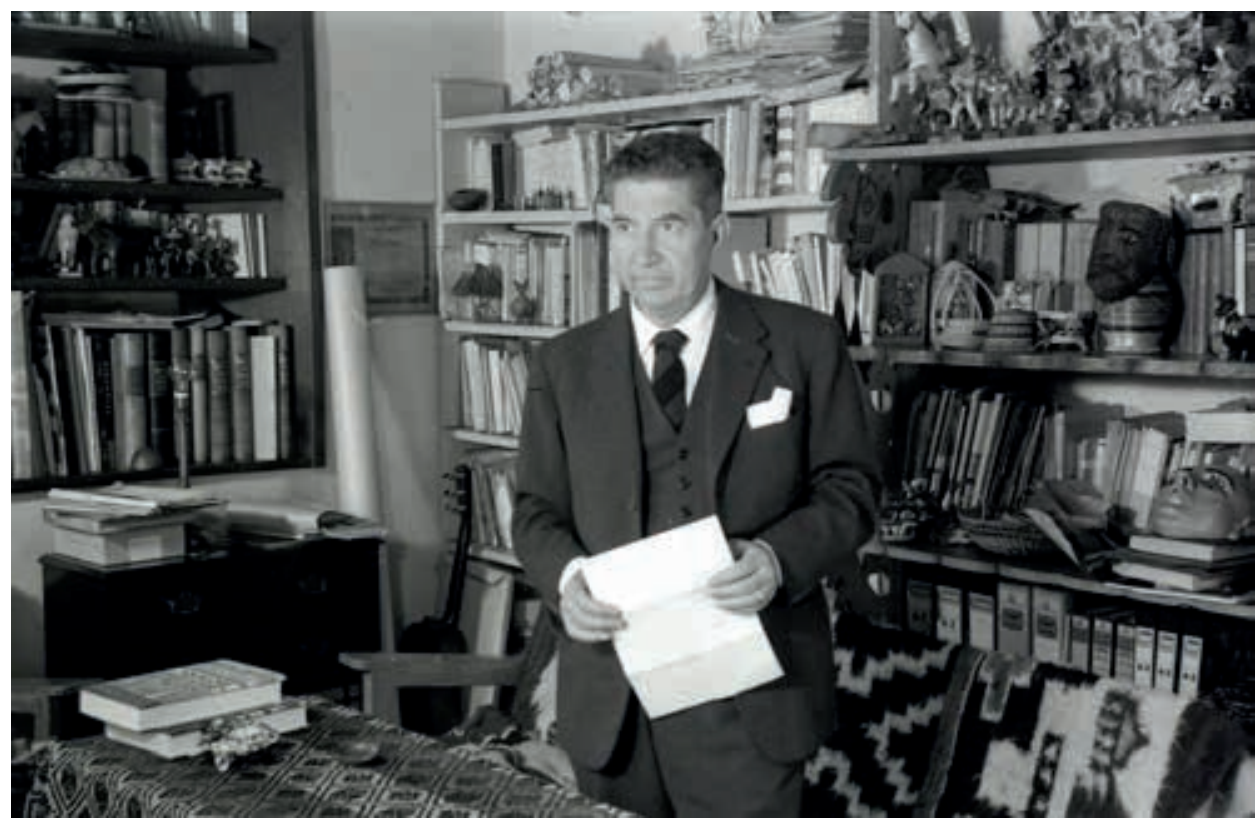

6. Tomás Lago in the MAPA surrounded by objects of popular art from Latin America. MAPA Collection, Universidad de Chile

The Dean of the Universidad de Chile's Department of Arts, Luis Oyarzún, shared a similar understanding of the popular arts. He, too, felt that "they embodied enduring traditions. Nevertheless, their immediate expression of life's necessities and the forms used stem from meaningful aesthetic language and interweave continuously with the most decanted abstractions". ${ }^{32}$

At a Universidad de Chile academic workshop, the Sociedad de Amigos del Arte Popular (Friends of the Popular Arts Society), represented by Norma Alarcón, Juan Domínguez Marchant and Ida González, redacted a document which argued that popular art was a part of folklore, in a similar way to what Tomás Lago had claimed. ${ }^{33}$ Moreover, they offered the following definition: "one could say that the popular arts are, on the one hand, formal, material and traditional expressions of the people, whose deepest roots are in the past and

${ }^{32}$ L. Oyarzún, Prólogo. Arte Popular Chileno. Definiciones, problemas, realidad actual. Mesa redonda de los especialistas chilenos convocada por la XIX Escuela de Invierno de la Universidad de Chile, con la colaboración de la UNESCO, Santiago, 1959.

${ }^{33}$ N. Alarcón, J. Domínguez Marchant and I. González, "Arte Popular y Artesanías. Artes Manuales en General. Arte Aplicado y Primitivo. Definiciones nacionales de estos conceptos", in: Arte Popular Chileno, p. 25. 
who survive thanks to the general public's desire to conserve. On the other hand, they are also spontaneous and instinctive expressions by popular artisans and artists who have not been educated systematically for the task" ${ }^{34}$ The document went on to explain more extensively some of the characteristics of this art: it is traditional, it is popular and it is anonymous. ${ }^{35}$

The Argentine Alberto Gerchunoff ${ }^{36}$ described Chilean popular art objects from his point of view as a foreigner. He defined popular art as a collective activity of the spirit and emotional unity in America, ${ }^{37}$ while he argued that there were similarities among the popular arts worldwide. ${ }^{38}$ Of most importance to this article is the portion of his writing which he dedicates to emphasizing that popular art is not exotic, and highlighting how important it is to leave behind traditional paradigms from bygone eras used to interpret Latin American cultural manifestations.

The definitions and discussions presented to this point were fundamental to Latin America and emerged around the same time as the MAPA, the first popular art museum on the continent. Over time, new generations of intellectuals would contribute to the creation of a solid theoretical body of knowledge for the evaluation of these arts. Ticio Escobar is one of the intellectuals from this generation.

Ticio Escobar's effort to rectify outdated European categories and paradigms and find new Latin America-specific ones is a major contribution to the theoretical body of knowledge that has increased the value of American popular arts. Escobar proposes breaking down the fixed boundaries between that which is considered popular and that which is considered intellectual, academic or fine, and opening up to diverse models of art. ${ }^{39}$ Popular art cannot be interpreted with the concepts imposed by modern thought, which demand formal autonomy based on the following premises: the separation between form and function (and the dominance of the former over the latter), indi-

${ }^{34}$ N. Alarcón, J. Domínguez Marchant, I. González, "Arte Popular y Artesanías. Artes Manuales en General. Arte Aplicado y Primitivo. Definiciones nacionales de estos conceptos", in: Arte Popular Chileno, p. 26.

35 Ibidem.

${ }^{36}$ Alberto Gerchunoff (1883-1950) was an Argentine writer and journalist who wrote for La Nación newspaper in Buenos Aires.

37 A. Gerchunoff, "El arte popular en Chile", in: Revista de Arte, Ańo III, N 18. (1938) Publicación bimestral de divulgación de la Facultad de Bellas Artes de la Universidad de Chile, p. 27.

38 Ibidem, p. 26.

39 T. Escobar, "Los desafíos del museo. El caso del Museo del Barro", in: El museo en escena. Política y cultura en América Latina, ed. A. Castilla, Buenos Aires 2010, p. 168. 
vidual ingenuity, originality and uniqueness. ${ }^{40}$ For Escobar, on the other hand, popular art should be studied and interpreted as based on its own occurrences and characteristics: art whose very nature inspires collective identification, and articulates solidarity and political response. ${ }^{41}$

In the new evaluation of these arts, the American continents were joined by Europe. Two of the twentieth-century phenomena that favoured the gradual valuation of Latin American cultural products were the consolidation of anthropology as a science and the embracing of the decorative arts in Western arts. These phenomena occur in the global context of the World Wars. Starting in the 1910s, the West experienced break-up up over these conflicts. Excessive confidence in Western culture and the idea of future progress was dead in the water, given the perceived failure of the European nations (and others involved) to resolve the World Wars and their atrocities. When Europe and its culture turned out not to be the keepers of the future of humanity, the West had no other option than to look to those parts of the world that had found themselves marginalized. Moreover, increased for the simple life and less complicated cultures and customs became greater valued. In this context, European visual arts set its sights and inspiration on arts from places like Africa, Australia and Latin America. This process began with the new valuation certain critics gave to "exotic" cultures exhibited in places like Trocadero in Paris. Roger Fry, who saw some African sculptures in Trocadero treated them as great sculptures and admired the technique and expressive strength they communicated..$^{42}$ Visits to Trocadero gave the opportunity to many artists to realize that the search for mimesis was not a worldwide norm. ${ }^{43}$ Then, painters such as Pablo Picasso, Paul Gauguin and Paul Klee were inspired by the geometric and abstract forms from cultures previously considered inferior, just as Henry Moore admired and emulated Mayan Chac Mool figures in his sculptures. Pre-Colombian and contemporary Latin American arts slowly became part of the history of culture as written by Europe.

Meanwhile, in the Americas, Pan-American movements were springing up, and one of their successes was safeguarding Latin Americanism itself in the visual arts, where a pre-Columbian past played an important role.

Latin American ideas regarding the arts mixed with the general PanAmerican efforts. In the Exhibition of Popular American Art catalogue, a wide

40 T. Escobar, El mito del arte y el mito del pueblo. Cuestiones sobre arte popular, Santiago de Chile 2008, p. 179.

${ }^{41}$ Ibidem, p. 13.

42 E.H. Gombrich, La preferencia por lo primitivo. Episodios de la historia del gusto y el arte de Occidente, Barcelona 2003, p. 218.

${ }^{43}$ Gombrich, La preferencia por lo primitivo, p. 221. 
variety of objects were introduced by a text that emphasized the importance of the Latin American countries' common inheritance and the fact "that the peoples and their arts were still pure. The Latin American objects showed a region rich in diversity and awe-inspiring in aesthetic" ${ }^{44}$

Latin Americanism ${ }^{45}$

In a famous 1891 essay published in New York, the Cuban intellectual José Martí made an appeal to the young Latin American countries to unite the Nuestra America (Our America) community in opposition to the United States' claim to the name American ${ }^{46}$ for its people. While Pan-Americanism $^{47}$ had existed in the region since the nineteenth century, ${ }_{18}^{48}$ it had had its ups and downs. The United States, which had adhered to an isolated and selfinterested international position during the nineteenth century, called an international American conference in 1889, which brought about the birth of coordination to encourage the integration of the countries on the two continents. ${ }^{49}$ Some of the important moments for Pan-Americanism in the twentieth century were the conferences in Montevideo in 1933 and the entrance of the United States into World War II in 1941. The North Americanization process inspired resistance to the cultural extreme of the United States. These feelings resulted in distrust of the United States' attitude, especially given that the Latin American nations fully rejected any form of imperialism. However, in spite of all the conflicts, both North and South America attempted to come together around democratic ideals, human rights, work and peace in the world at war. ${ }^{50}$

One important initiative of the renewed Latin Americanism at the end of the 1930s was the Convention for the Promotion of Inter-American Cultural Relations in 1936, also known as The Inter-American Conference for the Maintenance of Peace. The event, held in Buenos Aires, supports my thesis, because it indicates the importance attributed to culture as a field for the confluence of Latin American histories and styles. Furthermore, it presented

${ }^{44}$ Labarca, "Prefacio"..., p. 10.

45 "Latin America" includes Hispanic-American countries and Brazil.

${ }^{46}$ J. Martí, Nuestra América, Barcelona 2006.

47 The concept of Pan-Americanism includes the Hispanic-American countries, Brazil and the United States.

48 This movement, begun by the United States in 1889, resulted in diplomatic, economic and cultural integration of the American republics after conflicts caused by the fall of the Spanish Empire on the continent (1810).

49 Martí, Nuestra América, p. 6.

50 S. Guy, Hacia la solidaridad americana. Madrid 1924, p. 427. 
a conciliatory space for values and ideas about how to encourage peace. Professors, teachers and others unofficial agents met to create mechanisms to establish ties of academic cooperation among countries.

While the war was underway in Europe in the 1940s, Latin America was characterized by the strengthening of Latin Americanism. The continent provided a meeting ground for intellectuals, institutions and other Latin American agents who were seeking a shared identity and activities to strengthen their positions on World War II. The political and military sectors were tainted by the war and revealed their ineffectiveness in putting an end to it. Culture, on the other hand, was perceived as a universal field, distanced from specific political alliances and full of possibilities for agreements.

\section{THE HISTORICAL CONTEXT: INSTITUTIONS}

The Universidad de Chile and its interest in connecting to society

A sense of connection among Latin American nations is highly evident in the discourses and practices of several public institutions and agents.

In terms of institutions, the role of the University of Chile is noteworthy. ${ }^{51}$ On the heels of the Argentine University Reform of 1918, the University of Chile, a public institution, enthusiastically took up the call not to simply follow foreign models, but rather to focus on Latin American and Chilean realities. In 1938, the then-director of the Universidad de Chile created a discourse specifically dedicated to the extension of the university. For him, this meant "bringing the knowledge of the learned to the public-at-large, making techniques known and sharing research results typically available to only the few" ${ }^{\prime 52}$ The University would use two basic tools to go about this work: cultural extension conferences and winter/summer schools. The university

51 The Universidad de Chile's presence in the creation and development of the Museo de Arte Popular was not without precedent. One of this Latin American museum's most striking characteristics is its connection to universities. That is the case, for example, with the University of Mexico (1551), the University of San Carlos of Guatemala (1676), San Felipe in Chile (1738), which housed the first museums in Latin America during the $18^{\text {th }}$ century. This relationship consolidated during the $19^{\text {th }}$ century. This is due to the close ties between museums and the educational role assigned to them, as well as the knowledge concentrated within their walls. M.M. Lopes, "Compartir espacios, colgar ballenas y apoyar a las universidades", in: El museo en escena, p. 39.

52 J. Hernández, La extensión Universitaria, Informe de las Escuelas de Temporada 1935-1939, Santiago 1938, p. 417 available online: <http://www.revistas.uchile.cl/index. php/ANUC/article/viewFile/25429/28676> [accessed: May 17, 2018]. 
would thereby sustain a commitment to the popular arts. In partnership with UNESCO, many discussions were organized to establish diagnostics and strategies for this work. One of the outstanding proposals called for the creation of regional popular art museums and the incorporation of popular arts into school curriculum.

La Comisión Chilena de Cooperación Intelectual (The Chilean Commission on Intellectual Cooperation)

Of great importance for this article is the Comisión Chilena de Cooperación Intelectual (The Chilean Commission on Intellectual Cooperation) established within the Universidad de Chile. It was founded in 1930 with two main aims: to establish contact and coordination among the country's many cultural activities and to create spiritual connections abroad, making Chilean culture known to foreign countries and foreign cultures known in Chile. ${ }^{53}$ The Comisión Chilena de Cooperación Intelectual organized important international events, which were Pan-American, cultural initiatives. Of particular relevance was the organization of the First American Conference of National Committees on Intellectual Cooperation, held in Santiago in association with the League of Nations and attended by representatives from many Latin American countries and international organizations. The theme of the event was discussion of the mission Latin America might play as a contributor to peace $^{54}$. The aim of the meeting was very telling in terms of Latin American self-perception regarding the possibility of encouraging peace through culture at its borders and beyond. For this group, international relationships based on cultural aspects offered hope during a time of war. Throughout its early years, the organization produced many cultural events to bring the nations together. The most important of these, however, was the 1943 Exposición de Artes Populares.

When it came to creating connections with society, the Comisión Chilena de Cooperación Intellectual would set in stone its mission to support popular culture through a report completed in 1940. One point was that by strengthening and embracing its own culture, Chile would be in a better condition to collaborate with other nations. As the cultural diffusion proposed "was linked directly to production activities, it would be free from any one specific politi-

53 Comisión Chilena de Cooperación Intelectual. Veintidos ańos de labor. 1930-1952 [Chilean Committee on Intellectual Cooperation, Twenty-two years of work. 1930-1952], Santiago 1953, p. 5.

${ }^{54}$ Ibidem, p. 6. 
cal influence and would better serve the permanent interests of the nation" ${ }^{55}$ The report proposed direct work with citizens, teaching them arts and trades. By promoting the involvement of all social classes in cultural activities, the workers would be in better spiritual condition and produce more, an aim pursued by the Frente Popular ${ }^{56}$ in the 1940s.

The chancellery was also committed to the Pan-American idea; with the specific aim of developing a space in which the arts from Latin American countries could unite as ambassadors of their cultures. To this end, they called upon one organization in particular: the Agencia de Cooperación Intelectual (The Agency of Intellectual Cooperation). This group started in 1921 under the auspices of the League of Nations in order to restore and invigorate the areas of literature, art, science and education after World War I. This institution had three goals: (1) to improve the material conditions of intellectual workers; (2) to encourage international relationships and contacts among professors, artists, scientists, authors and members of other intellectual professions; (3) to strengthen the society's influence on peace, with the knowledge that intellectual workers, university professors and school teachers in particular are a virtually untapped resource from an international-policy point of view.

\section{ORGANIZATION OF THE EXHIBITION}

Several diplomatic sources make it possible to follow the organization of the 1943 Exhibition. Documents dating back to early 1940 refer to an event to be held at the Museo Nacional de Bellas Artes in Santiago, Chile in 1943. The preparations make clear the importance of the Universidad de Chile, which would celebrate its 100-year anniversary with large-scale events. The public nature of the institution and its relationships with the rest of Latin America, as well as the specific political context of the time, explain why there was interest in bringing together Latin American objects in a temporary exhibition seeking a permanent existence. In this way, the university and its agents connected Latin American local life with Latin American life in general by bringing together daily life and functional objects from the far-flung corners of the continent.

55 "Cultura Popular." A report presented to the Comisión Chilena de Cooperación Intelectual by Mr. Osvaldo Vial and Mr. Santiago Ureta, Santiago 1940, p. 5.

56 El Frente Popular was a left-wing political conglomerate led by Chilean presidential candidate Pedro Aguirre Cerda in the year 1938. 
Convención para el Fomento de Relaciones Culturales

(Convention for the Promotion of Cultural Relations)

The proceedings for organization of the 1943 exhibition were institutional and diplomatic. They raised the bar for the cultural exchanges already taking place in Latin America, many of which were the tangible result of the 1936 Buenos Aires meeting, by way of Article II from the Convención para el Fomento de las Relaciones Culturales.

In 1940, the Chilean Commission sent Latin American governments invitations to participate in the Exhibition of American Popular Art. These letters explicitly referred to the university's third mission in that they invoked the common past and offered a definition for popular art. The letter ended with a "nómina" of popular art objects, which indicated how objects might be divided into categories. It is interesting to note that the first classification criteria was the function of the object, and second, its material. This reveals two points: an insistence that the object be in daily use and the variety of primary materials Latin America had to offer.

Subsequent letters requested that the countries sponsor a series of activities to promote participation of their peoples in sending objects and, in the event of receiving several items, that they send the best and most representative to Chile. They also asked for the assistance of the press in publicizing the event. From the beginning, the donation of objects sent to Chile was encouraged. They stated that after the commemorative exhibition finished, the objects could remain to form a part of the Latin American popular art permanent collection.

Once each country had been invited, by way of the aforementioned letter, a variety of agents and institutions took over organization of the event. Relevant diplomatic correspondence suggests the economic and operational challenges presented by some of the shipments. However, there were also problems of a different nature: Guatemala, through an interesting confidential letter to Chile's Minister of Foreign Affairs showed an interest in the Universidad de Chile's centennial, but found it impossible to participate in the celebration because they were involved in World War II. Other countries could not participate in the exhibition due to difficulties caused by the war. For example, while Brazil was interested in participating, it could not because it lacked transport options.

\section{The Exhibition}

The exposition opened on April 17, 1943, coinciding with the completion of activities celebrating the Universidad de Chile's centennial. It was held in the Sala Chile at the Museo Nacional de Bellas Artes and was highly ac- 
claimed. In fact, it was forced to remain open an extra month due to the flow of people in and out of its doors. ${ }^{57}$ The Chilean press praised the objects sent by the participating countries and the work of Tomás Lago, the great founder and organizer of the event. Alberto Reid, a Chilean journalist, beautifully describes the exhibition: "For the first time in our country, eight fraternallyunified Latin American countries, under the auspices of the Universidad de Chile, have successfully put together one of the most interesting and beautiful exhibitions ever seen" ${ }^{\prime 58}$ Reid also states that the exhibition catalogue will be of great use to subsequent study of Latin American popular art.

Pablo Neruda ${ }^{59}$ himself praised the exhibition and stressed the importance of taking away from it an understanding of "the acrimony and sweetness of the nameless; and recognizing the silence of our people, whom we may give wholeheartedly and peacefully word and hope because the people have nothing yet deserve everything" ${ }^{60}$

Tomás Lago's wishes materialized: the countries donated the objects they had sent to the exhibition and the collection for the Museum of American Popular Art was created. It was inaugurated on December 20, 1944 at Hidalgo Castle on Santa Lucia Hill. At the time, the museum was considered one of the continent's best and most complete. ${ }^{61}$ This was just the beginning of a life and an institution dedicated to the valuation and promotion of popular art in Chile and in relation with other Latin American countries.

57 The art critic Alfredo Aliaga's words are telling: "The popular art exhibition, inaugurated on April $17^{\text {th }}$ at the National Arts Museum, will be extended by one month due to the great flow of visitors through its doors". A. Aliaga, En Viaje Magazine, N 116, June 1943, Santiago, p. 52. The exhibition's success with the people of Santiago is also discussed in: "Exposición de Artes Populares Americanas organizada por la Universidad de Chile", Zigzag Magazine, Santiago, March 1943; "Exposición de Artes Populares", El Mercurio April $12^{\text {th }}$, Santiago, 1943.

58 The text continues: "Another important element of this exhibition is that in the future it should play a permanent educational role. We do not know where the Universidad de Chile will go to find this beautiful material. Our desire is simply that a permanent collection of popular arts be amassed once and for all". A. Ried. "Beneficios de la exposición de arte popular", in: Las Últimas Noticias, ańo XLI, Friday, April 30, 1943, Santiago, p. 3 and A. Ried, "Exposición Interamericana de Arte Popular", Las Últimas Noticias, year XLI and year XLI, Monday, March 1, 1943, Santiago, p. 3.

59 Pablo Neruda (1904-1973) was a Chilean poet who received the Nobel Prize for Literature in 1971 . He was also a leading political activist, senator, member of the Communist Party and Chilean Ambassador to France.

60 Pablo Neruda in Ars Todas las Artes, N 20 and 21, Buenos Aires, 1943.

61 Comisión..., p. 8. 


\section{OPERATION OF THE MAPA}

The objects collected for the Exhibition of American Popular Art in 1943 stayed in Chile to form part of the permanent collection at the Museum of American Popular Art Tomás Lago (MAPA). During this stage of life for these objects they can be characterized as artefacts from a museum concerned with the acquisition of new pieces, and the creation of discourses and strategies for the consolidation of popular Latin American art and its public image.

The MAPA's first years are entwined inseparably with Tomás Lago: he was essential to the organization of the exhibition, the creation of the collection and the museum's functioning during its first few years. His contacts included many cultural leaders and institutions in the Latin American countries with whom he corresponded to share publications, ideas and Latin American objects, which inevitably led to an increase in their valuation. Examination of Lago's correspondence as head organizer of the Exposición de Artes Populares and Director of the MAPA helps us understand his character and his ideas about the development of popular, folkloric and traditional art concepts. Tireless, passionate and silent in his work, Tomás Lago dedicated his life to leaving his ideas in books and at his namesake museum.

The network of intellectuals he put together is evident from his relationships. His counterparts shared his values and discussed the importance of conserving and disseminating Latin American popular culture. For example, Tomás Lago wrote a letter to Gabriela Mistral in 1942, when the poetess was in Brazil. In the letter he asked for her help in finding Brazilian pieces for the Exposición de Artes Populares he was organizing. He enumerated the Latin American countries who were sending objects in order that Brazil would send theirs as well. We also know from his correspondence that in 1960 the wife of Peru's former President donated a series of objects to the Museo de Artes Populares to enrich its collection of Peruvian objects. In 1971, a considerable donation was received from the President of Argentina's Sociedad Rural de Tucumán. Donations from Chile also arrived, such as a collection of painted clay items from Talagante. ${ }^{62}$

However, Lago was so preoccupied with the idea that the objects should be of the highest quality that he was open to receiving offers from private parties in different countries and from the very artisans who offered their crafts for the collection. Examples of the former include the exchange of objects made among several countries under the watchful eye of the Foreign Rela-

${ }^{62}$ Letter from Tomás Lago to Rafael Vega Gerap, September 9, 1958, Santiago. MAPA Archive (Santiago, Chile). 
tions Ministry, ${ }^{63}$ and the exchange of popular art publications between the MAPA - from the Universidad de Chile - and other universities in and outside of Chile. ${ }^{64}$ Examples of the latter include objects made and donated by an artisan from Mulchén, a small town in the south of Chile, as indicated in a letter from June of 1959 he sent to Lago. I found his words quite eloquent: "I, like Rubén Bizama, am a shoemaker (married, five children). During my limited free time, I paint oil paintings as a hobby and leisure activities, some are copied from magazine photographs and others are of my own inspiration. I wonder, Sir Director, if it would be possible for you to accept two or three of my paintings for the exhibition and if so, I would happily send them" ${ }^{65}$

In this subsection on acquisitions of new Latin American objects for the museum, it is worth noting that the influx went beyond donations and exchanges. The MAPA had to buy artefacts from many parts of the world in order to increase their permanent collection and make it as representative as possible. Purchase invoices for these objects can be found in the institution's archives and they show the process to have been systematic, organized and transparent.

Thanks to the management of Tomás Lago, Chilean popular arts were present in many Latin American and North American institutions. At the beginning of the 1960s, the director of the MAPA wrote a book called Arte Popular Chileno, which was published by the Universidad de Chile in collaboration with UNESCO. Lago himself ensured it was sent to the most important Latin American, North American and European institutions interested in the phenomenon and its catalogue. The MAPA's archive contains proof that this publication was sent to the Museum of New Mexico, the Musee des Arts et Traditions populaires (Director Georges Henri Riviére), a professor from the Universidad Central de Ecuador, the Universidad Nacional Mayor de San Marcos in Lima, the General Director of Culture from Argentina's Ministry of Education and Justice, the OAS Headquarters in Washington DC and UNESCO's headquarters in Havana, Cuba. I find particularly significant the thank-you letter from this last institution, because it shows the importance of this type of publication as a model for other Latin American nations to follow.

${ }^{63}$ Letter from Francisco Walker Linares, General Secretary of the Comisión Chilena de Cooperación Intelectual (Chilean Commission for Intellectual Cooperation), Tomás Lago, Santiago, March 23, 1953. MAPA Archive.

${ }^{64}$ Letter from María C. Tijerina, of the Universidad de Nueva León, February 22, 1950, MAPA Archive.

${ }^{65}$ Letter from Manuel A. Castillo T. to Tomás Lago, Mulchén, June 10, 1959, MAPA Archive. 
Due to its identity as a state institution, the Universidad de Chile authored many of the textual resources accompanying the popular art objects. Likewise, the Universidad de Chile, which the MAPA reported to, collaborated in the dissemination of popular art. In the 1940s, the university extended activities to include Summer and Winter Schools at which handicrafts were taught and popular arts were discussed.

The more important tacit discourse accompanying these Latin American popular art objects is one related to peace and democratic values. Although Lago never explicitly related to the uplifting of popular arts to peace, he did comment on the reception and social valuation of his efforts made towards a peaceful and civic position on the problems afflicting the world at the time. Testimony is found in the letter he received in 1955 from the Secretariat of the World Peace Council, in which he was invited to Vienna to participate in the World Assembly for Peace held in Helsinki from May 22 to 29, 1955. The letter states that the conference was being held to create a world peace climate given the imminence of nuclear war. ${ }^{66}$ It insists on the importance of a diverse body of participants in order for dialogues to take place related to contemporary cultural problems and the moral and physical situation. The letter ends by emphasizing the importance of intensifying scientific, artistic and technical exchanges and collaboration among nations. Furthermore, the importance of defending and developing national cultures is discussed in the context of the hateful sentiments among the countries that had started the war, sentiments that would continue for some time. It is easy to imagine why, amid such a climate, the Assembly might have called upon Tomás Lago, embodied by the museum objects, to speak about cultural exchange, to seek cultural solutions and to show the importance of exalting the many countries' popular arts through their functional objects in daily use.

In 1956, a group of Argentinians, led by the lawyer and art critic Norberto Frontini, honoured Tomás Lago and recognized him for his noble citizenship, for having highlighted the true cultural value of the Latin American peoples and for having dedicated himself so completely to making them known. ${ }^{67}$

Europe's traditional discourse of superiority and diplomacy as a form of problem solving had become obsolete and useless. The historic ideal of a united Europe dissipated in the face of war. New cultural horizons, new symbols and new dialogue strategies had to be sought out to replace the European par-

${ }^{66}$ Letter from El Secretariado del Consejo Mundial de la Paz to Tomás Lago, Vienna, April 14, 1955. MAPA Archive.

${ }^{67}$ Letter from María Rosa Oliver to Tomás Lago, dated May 22, 1956, Buenos Aires, MAPA Archive. 
adigms, whose failure was exposed by the two world wars. Latin America and its culture, both on its own continent and from the debilitated European point of view, were thought of as a land of hope. Latin American identity could be appreciated in many forms. Popular arts were among the agents cultivating values, perceived as so different from those of Europe, and were foreshadowers of the important role the Latin American continent would play in the future. Latin American identity could be appreciated in many forms. American popular arts entailed a discourse that recovered the values of tradition that in some way placed them above the ideal of unrestrained progress established in Europe prior to the wars. Popular arts reclaimed the importance of handcrafting in response to the machine discourse imposed by European industrialization. In this atmosphere of binary oppositions, it was not odd, after the failure of the European paradigm, to see Latin America and its popular arts become representative of peace. This collection showed the visible differences between European and Latin American cultural productions.

Additionally, Lago's initiative placed value on the search for common characteristics shared among the Latin American countries; quite the opposite of what was happening on European continent as it broke into factions. Regarding the exhibition's success, Tomás Lago said that "the eloquence of the events was proof of the strength of Latin American racial kinship" ${ }^{68}$

Recognition of Lago's work by Europe and the Americas substantiates his close ties to peace efforts.

\section{CONCLUSIONS}

The mediating objects arriving from other countries to Chile, debuted in an exhibition and then remained in a museum as representatives of their nations. They embodied a series of discourses and processes. One of these was the potentially fluid status of these objects, the possibility of the fluid movement of these objects among different cultures and countries which could define themselves as neighbouring societies having experienced similar influences. ${ }^{69}$ The context of World War II and the regional impossibility of finding political and military agreement turned culture and its objects into

68 T. Lago, "Misión del Museo de Arte Popular", in: Antártica. Panorama de la actividad mundial, N 9, May 1945, Santiago de Chile, p. 89.

69 T. DaCosta Kaufmann, C. Dossin, B. Joyeux-Prunel, "Introduction: Reintroducing Circulations: Historiography and the Project of Global Art History", in: Circulations in the Global History of Art, London-New York 2015, p. 6. 
a favourable space for communication, a space to show rather than tell. ${ }^{70}$ In this sense, the objects in their trajectory fostered ideas and values, the idea of a shared identity and a value for peace. In creating a shared and articulated feeling with regards to culture in the broader sense, transcendence of tense international conflicts was believed possible. This, along with other processes that offered contextual value to popular art, glorified the objects and made them worthy of entrance into the museum. Each exhibition piece was a Latin American object in daily use, while it was also representative of what it meant to "be Latin American". Precisely because traditional culture and functional cultures nourished this exhibition with artefacts and utensils in use, a political declaration of the commonalities of the continent was not necessary. Its "essence" was found in each of the many diverse objects from the exhibition.

Not only did this feeling manage to lift the Latin American spirit, it also gave hope to the rest of the world. At the beginning of 1943, a time of war throughout the world, the reality of the Latin American continent was one of peace. In this way, Latin America created an exhibition and then a museum that sought to emphasize a shared identity by way of its objects.

The new valuation of the objects elevated them to be considered pieces of art. While Tomás Lago never doubted that they belonged to the realm of art, it must be remembered that the countries invited were asked to donate pieces that were in active use. Their inherent value lay therefore in their usefulness to the daily lives of the people and in their ability to represent the culture that had created them. But, subsequently, they were exhibited as popular art in an exhibition that valued them neither ethnographically nor historically, but strictly artistically. This new possibility for popular art should not be understood as a mere deconstruction of the binary distinctions between high culture and popular culture, but rather, as Ticio Escobar proposes, as differences evolving from specific historic processes that transpired..$^{71}$

\section{BIBLIOGRAPHY}

Acuńa C., Origen y devenir del Museo de Arte Popular Tomás Lago; pdf available online: <http://www.mapa.uchile.cl/proyectos/index.php> [accessed: May 16, 2018] Alarcón N., Domínguez Marchant J. and González I., "Arte Popular y Artesanías. Artes Manuales en General. Arte Aplicado y Primitivo. Definiciones nacionales de estos conceptos", in: Arte Popular Chileno. Definiciones, problemas, realidad ac-

${ }^{70}$ C. Cox, Making Art Panamerican. Cultural Policy and the Cold War, Minneapolis 2013, p. XVI.

${ }^{71}$ Escobar, El mito del arte..., p. 16. 
tual. Mesa redonda de los especialistas chilenos convocada por la XIX Escuela de Invierno de la Universidad de Chile, con la colaboración de la UNESCO, Santiago 1959

Alpers S., "The Museum as a Way of Seeing", in: The Poetics and Politics of Museum Displays, eds. I. Karp and S.D., Lavine, Washington-London 1991

Canal Feijoo B., "Argentina", in: Catálogo Exposición Artes Americanas. Realizada con motivo del Primer Centenario de la Universidad de Chile, Santiago de Chile 1943, pp. $15-16$

Comisión Chilena de Cooperación Intelectual. Veintidos ańos de labor. 1930-1952 (Chilean Committee on Intellectual Cooperation, Twenty-two years of work. 1930-1952) Santiago 1953

Cox C., Making Art Panamerican. Cultural Policy and the Cold War, Minneapolis 2013

Da Costa Kaufmann T., Dossin C., Joyeux-Prunel B., "Introduction: Reintroducing Circulations: Historiography and the Project of Global Art History", in: Circulations in the Global History of Art, London-New York 2015

Dant T., Material culture in the social world: values, activities, lifestyles, Buckingham 1999

Escobar T., El mito del arte y el mito del pueblo. Cuestiones sobre arte popular, Santiago de Chile 2008

Escobar T., "Los desafíos del museo. El caso del Museo del Barro", in: El museo en escena. Política y cultura en América Latina, ed. A. Castilla, Buenos Aires 2010

Ferrer Orts A., A. Madrid Letelier, "Las grandes líneas maestras de la historiografía artística chilena (1928-1965)", Saitabi. Revista de la Facultat de Geografía i Historia 2016, 66

Gell A., "Vogel's Net: Traps as Artworks and Artworks as art", Journal of Material Culture 1996, 1(15)

Gerchunoff A., "El arte popular en Chile", Revista de Arte, Ańo III, N 18. (1938) Publicación bimestral de divulgación de la Facultad de Bellas Artes de la Universidad de Chile

Gombrich E.H., La preferencia por lo primitivo. Episodios de la historia del gusto y el arte de Occidente, Barcelona 2003

González de Oleaga M., E. Bohoslavsky, M. di Liscia, "Entre el desafío y el signo. Identidad y diferencia en el Museo de América de Madrid", Alteridades 2011, 21(41), p. 1

Guy S., Hacia la solidaridad americana, Madrid 1924

Hernández J., "Prefacio", in: Catálogo Exposición Artes Americanas. Realizada con motivo del Primer Centenario de la Universidad de Chile, Santiago de Chile 1943

Hernández J., La extensión Universitaria, Informe de las Escuelas de Temporada 1935-1939, Santiago1938, available online: <http://www.revistas.uchile.cl/index. php/ANUC/article/viewFile/25429/28676> [accessed: May 17, 2018]

Karp I., Lavine S.D., "Introduction: Museums and Multiculturalism", in: The Poetics and Politics of Museum Displays, eds. I. Karp and S.D., Lavine, Washington-London 1991 
Labarca A., "Prefacio", in: Catálogo Exposición Artes Americanas. Realizada con motivo del Primer Centenario de la Universidad de Chile, Santiago de Chile 1943

Lago T., "Las Artes Populares en Chile", in: Catálogo Exposición Artes Americanas. Realizada con motivo del Primer Centenario de la Universidad de Chile, Santiago de Chile 1943

Lago T., Arte Popular Chileno, Santiago 1971

Lopes M., "Compartir espacios, colgar ballenas y apoyar a las universidades", in: El museo en escena. Política y cultura en América Latina, ed. A. Castilla, Buenos Aires 2010

Martí J., Nuestra América, Barcelona 2006

Oyarzún L., Prólogo. Arte Popular Chileno. Definiciones, problemas, realidad actual. Mesa redonda de los especialistas chilenos convocada por la XIX Escuela de Invierno de la Universidad de Chile, con la colaboración de la UNESCO, Santiago 1959

Rinesi E., "El museo como ideología y como posibilidad", in: Museos. Arte e Identidad. Artesanías en la idea de nación, compiled by E. Rinesi, Buenos Aires 2011

Sánchez Narváez E., "Bolivia", in: Catálogo Exposición Artes Americanas. Realizada con motivo del Primer Centenario de la Universidad de Chile, Santiago de Chile 1943

Subercaseaux B., Historia de las Ideas y de la Cultura en Chile Volumen III, Santiago 2011, p. 100

Olaya Sanfuentes

History Department

Pontificia Universidad Católica de Chile, Santiago

LATIN AMERICAN POPULAR ART IN A MUSEUM:

HOW THINGS BECOME ART

Summary

In 1943 when Universidad de Chile celebrated its centennial all Latin American nations were invited to participate in the commemorative events. One of the most interesting was the Exhibition of American Popular Art at the Museo Nacional de Bellas Artes (National Museum of Fine Arts) which brought together the objects from participating countries. The Universidad de Chile's invitation asked countries to send functional objects that were part of the people's daily lives. The exhibition was very successful, critically acclaimed, and highly attended. But above all, it planted the seed for what was to become the Museo de Artes Populares Americanas (American Popular Art Museum) functioning to this day.

In this essay I would like to highlight a series of contexts, actors and institutions behind the phenomena: specific incarnations of Pan Americanism during the Second World War; the Latin American perspective in general and in particular, the Chilean perspective of the university's role in society; the new value of Latin American arts since the $20^{\text {th }}$ century. These contexts and events are useful to shed light on the "social 
life" of the objects that were part of the exhibition and they also help us to understand a dynamic definition of art which emerged from the recognition of craft in use as worthy of exhibition in a National Fine Arts Museum and then to remain at the permanent collection of a popular art museum.

The radical importance of this essay is that it constitutes an example of a thing which represents not just art but also other values. In a midst of the World War II, Latin American Popular Art represented peace. The objects of the exhibition were seen as incarnations of Latin American cultural identity and historiography has gone on to view Latin American culture as a specific contribution to peace effort.

Keywords:

Latin American art/ Popular Art/ social live of things/Panamericanism/crafts 
